\title{
PENGARUH PENGEMBANGAN PRODUK TERHADAP VOLUME PENJUALAN PADA TOKO ROTI MM MADIUN
}

\author{
Zulfiana Luthfi Hanifah \\ Mahasiswa Prodi. Pendidikan Ekonomi IKIP PGRI Madiun
}

\begin{abstract}
Abstrak: Penelitian ini bertujuan: a) untuk menentukan pengembangan produk dari produk pada "MM-Madiun Toko Roti", b) untuk menentukan volume penjualan pada "MMMadison Toko Roti", c) untuk menentukan apakah ada pengaruh antara pengembangan produk dengan volume penjualan pada "toko roti MM-Madiun" dan sampel dalam penelitian ini menggunakan purposive sampling dari penjualan selama 6 bulan. Untuk mengumpulkan data menggunakan wawancara dan dokumentasi. Dalam menganalisis data menggunakan metode analisis statistik uji t dengan perhitungan uji SPSS versi 16.0. Data yang digunakan dalam analisis adalah volume penjualan data sebelum dan setelah pengembangan produk selama 6 bulan. Hasil penelitian menunjukkan bahwa pengembangan produk memiliki efek yang berbeda pada volume penjualan di toko roti MMMadiun. Hal ini berasal dari nilai $t$ adalah $\mathrm{t}_{\text {hit }}-2327$ sedangkan nilai $\mathrm{t}_{\text {tab }} 1795$. Di sisi lain, nilai $\operatorname{sig}_{\text {hit }}$ adalah 0,038 dan nilai $\operatorname{Sig}_{\text {prob }}$ adalah 0,05. Ini berarti bahwa $t_{\text {hit }} \geq t_{\text {tab }}(-2327 \geq 1,795)$ atau $\mathrm{Sig}_{\text {hit }} \leq \operatorname{Sig}_{\text {prob }}(0,038 \leq 0,05)$ menunjukkan penolakan $\mathrm{H}_{0}$ berarti bahwa pengembangan produk memiliki pengaruh yang berbeda pada volume penjualan di toko roti MM-Madiun.
\end{abstract}

Kata kunci: Pengembangan Produk, Volume Penjualan

\section{PENDAHULUAN}

Keadaan dunia usaha yang semakin berkembang menjadikan banyak perusahaan bersaing untuk mendapatkan perhatian dari masyarakat luas agar produk yang dihasilkannya dapat terjual dengan hasil yang memuaskan, Sehingga mampu menambah penghasilan perusahaan. Dengan semak in bertambahnya pendapatan dari hasil penjualan produknya, maka perusahaan tersebut dapat mempertahankan perkembangan usahanya.

Keinginan dan tuntutan pelanggan selalu berkembang sejalan dengan perkembangan ilmu pengetahuan, sosial, teknologi dan ledakan informasi yang telah mengakibatkan cepatnya perubahan selera pelanggan. Untuk mewujudkan keinginan pelanggan tersebut imajinasi dan inovasi sangat diperlukan agar dapat memenuhi permintaan pasar akan selera dan keinginan para konsumen. Inovasi baru atau pengembangan produk melalui perubahan bentuk, kemasan, ataupun variasi rasa baru akan menambah minat pembeli untuk mencoba olahan produk baru tersebut. Sehingga dapat meningkatkan volume penjualan.

Seiring dengan berkembangnya zaman, berbagai sektor dalam bidang ekonomi terus mengalami perubahan. Salah satu u saha yang mudah dan tidak membutuhkan modal yang cukup besar untuk memulainya adalah usaha home industri. Home industri merupakan usaha rumahan atau industri kecil yang bisa dikelola sendiri oleh keluarga. Seiring dengan semakin meningkatnya kebutuhan keluarga, dengan membuka usaha home industri akan mampu menambah penghasilan keluarga.

Toko roti MM Madiun merupakan salah satu home industri yang bergerak dalam bidang pembuatan roti yang mengolah bahan mentah menjadi makanan yang siap dikon- 

sumsi oleh masyarakat. Di dalam melakukan proses produksi, suatu perusahaan industri tersebut harus memperhatikan selera dan keinginan konsumen, serta dapat memberikan kualitas dan penampilan terbaik, agar produk yang dihasilkan dapat diterima dengan baik pula oleh masyarakat. Barang produksi yang dikemas dengan baik pasti akan menarik konsumen untuk datang membelinya dan dapat menambah pendapatan untuk home industri tersebut.

Pengembangan produk yang dilakukan home industri roti madiun dapat meningkatkan volume penjualan. Dengan adanya perubahan pada kemasan yang menarik akan mampu meningkatkan volume penjualan dan dapat meningkatkan penghasilan untuk industri tersebut. Penghasilan di sini bisa dipengaruhi oleh besarny a volume penjualan. Volume penjualan merupakan jumlah total yang dihasilkan dari kegiatan penjualan barang (Freddy Rangkuti, 2009:58). Dengan demikian semakin besar jumlah penjualan yang dicapai home industri dalam hal ini toko roti MM Madiun, laba yang diperoleh akan semakin besar.

Produk adalah segala sesuatu yang dapat ditawarkan ke pasar untuk mendapatkan perhatian, dibeli, dipergunakan atau dikonsumsi dan yang dapat memuaskan keinginan atau kebutuhan (Thamrin Abdullah dan Francis Tantri, 2012: 153).

Menurut Boyd, Walker, Larreche (2000:264) mengemukakan bahwa "produk dapat didefinisikan sebagai apa saja yang dapat memenuhi keinginan atau kebutuhan dalam hal penggunaan, konsumsi, atau akuisi".

Sedangkan Gunawan Adisaputro (2010:170) menyatakan bahwa "produk dapat diartikan sebagai sekelompok nilai yang memberikan kepuasan pada pemakainya”.

Di lain pihak Basu Swastha dan Ibnu Sukotjo (2002: 194) mengatakan "produk adalah suatu sifat yang komplek baik dapat diraba, termasuk bungkus, warna, harga, prestise perusahaan dan pengecer, pelayanan perusahaan dan pengecer, yang diterima oleh pembeli untuk memuaskan keinginan atau kebutuhannya".

Sedangkan untuk pengembangan produk Zulian Yamit (2005:100) mengatakan "pengembangai sektor dalam bidang e perusahaan untuk senanticapai home industri dalk baru, memperbaiki produk lama atau memodifikasi produk lama, agar selalu dapat memenuhi tuntutan pasar dan selera pelanggan".

Selain itu Basu Swastha (2002:95) mengatakan pengembangan barang (product development) ini merupakan suatu istilah yang lebih terbatas dibandingkan dengan perencanaan barang, yaitu mencakup kegiatan teknis tentang penelitian, pembuatan dan pen-disain-an barang.

Di lain pihak Agus Ahyary (2002:126) menyatakan pengembangan produk adalah "merupakan suatu penelitian terhadap produk yang sudah ada untuk dikembangkan lebih jauh lagi agar mempunyai tingkat kegunaan yang lebih tinggi, dan lebih disukai oleh para konsumen.

Faktor-faktor yang melatarbelakangi pengembangan produk adalah:

1. Faktor eksternal: a). Munculnya produkproduk sejenis dengan berbagai kelebihan, sehingga banyak home industri yang melakukan perubahan atau melakukan pengembangan pada hasil produksinya agar dapat bersaing dengan industri lain dalam usaha meningkatkan volume penjualan. b). Munculnya produk-produk baru yang lebih bagus dan menarik sehingga dapat menggantikan produk lama. Munculnya produk baru yang dikeluarkan oleh industri lain menjadikan penurunan penjualan pada home industri yang masih bertahan pada produk lama. Dengan demikian pengembangan produk harus segera dilakukan untuk menggantikan produk lama dengan produk yang baru. Sehingga usaha pengembangan produk yang telah terlaksana diharapkan dapat mePengembangan produk yang dil 
pada unit yang diinginkan. c). Pergeseran keinginan konsumen dan kebosanan terhadap produk-produk lama. Keinginan dan selera konsumen selalu berkembang seiring dengan perkembangan zaman, sehingga perusahaan dituntut untuk bisa memberikan produk baru yang sesuai dengan selera dan keinginan konsumen. d). Siklus hidup produk yang cenderung memendek mengakibatkan produk semakin tidak disukai konsumen, sehingga produk yang telah mengalami masa kemunduran harus segera dilakukan perubahan dengan memberikan inovasi tambahan yang menarik.

2. Faktor internal: a). Memperbaiki kinerja produk dengan memberikan berbagai kelebihan pada produk yang dihasilkan. Produk baru dengan penambahan manfaat ataupun atribut produk baik kemasan ataupun kualitas dapat menjadikan produk tersebut semakin dicari oleh konsumen, karena dengan model kemasan yang baru dan penampilan yang menarik dapat membuat pelanggan membeli produk tersebut, sehingga perusahaan dapat menambah keuntungan dari hasil penjualan yang diperoleh. Semakin tinggi tingkat penjualan, semakin tinggi pula laba yang diperoleh perusahaan home industri tersebut. b). Melakukan perubahan produk, salah satunya adalah pada kemasan. Kemasan merupakan hal yang sangat penting untuk melindungi produk, kemasan yang menarik, mudah dibuka dan dengan model serta warna yang cerah, menjadikan barang produksi tersebut banyak diminati oleh konsumen. c). Mempertahankan segmen dan pangsa pasar baru. Dengan adanya pengembangan produk diharapkan perusahaan home industri dapat memenuhi permintaan pasar dengan memberikan produk baru. Produk baru yang dihasilkan melalui tahapan penelitian tentang selera dan keinginan konsumen, akan banyak dibeli dan disukai oleh konsumen sehingga home industri tersebut dapat mempertahankan tingkat penjualannya. d). Memanfaatkan sumber daya manusia (karyawan maupun tenaga ahli) yang kemampuannya semakin bertambah melalui proses pembelajaran yang telah dialaminya, diharapkan dapat menghasilkan produk yang berkualitas dan dapat bersaing dengan industri lainnya. e). Menjaga kelangsungan hidup home industri dengan berusaha melakukan peningkatan volume penjualan, dengan demikian pendapatan yang diperoleh dapat menjadikan industri semakin berkembang.

Adapun tahap-tahap pengembangan produk adalah:

1. Tahap pengembangan gagasan. Banyaknya sumber gagasan atau ide yang dapat dimanfaatkan menyebabkan pengembangan gagasan harus dilakukan secara sistematik dan diseleksi terlebih dahulu untuk menentukan gagasan yang paling baik, sehingga dapat dihindari gagasan yang tidak relevan dan tidak realistis. Dalam melakukan pengembangan gagasan, perlu dilakukan strategi yang benar-benar jelas agar pengembangan dapat berjalan sesuai dengan strategi yang telah ditetapkan.

2. Tahap penyaringan gagasan. Tahap ini dilakukan setelah berbagai macam ide tentang produk sudah tersedia dari berbagai sumber. Sumber informasi atau ide dapat diperoleh dari pemilik industri, pendapat dari pelanggan dan pesaing. Tujuan penyaringan gagasan adalah untuk mengurangi dan memilih gagasan yang ada untuk diperoleh gagasan yang paling baik agar benar-benar dapat diwujudkan, sesuai dengan kebijakan dan strategi perusahaan. Keputusan untuk menerima atau menolak gagasan yang diragukan harus diambil sedini mungkin untuk mencegah pemborosan waktu dan dana.

3. Tahap pengembangan dan uji konsep. Dalam tahap pengembangan dan uji 
konsep ini gagasan yang telah disetujui kemudian dikembangkan menjadi konsep produk yang nantinya akan diproduksi. Pertama dirumuskan gagasan produk, yaitu gagasan tentang sebuah produk yang menurut perkiraan sementara dapat dibuat dan dipasarkan. Dari gagasan ini kemudian dikembangkan konsep produk, yaitu pemikiran yang lebih matang yang dirumuskan dalam rumusan pemasaran. Setelah semua proses produksi dilakukan selanjutnya dilakukan uji konsep sebagai kelanjutan dari tahap pengembangan. Dalam konsep pengujian dapat dilihat seberapa besar minat dan kesukaan konsumen terhadap produk baru yang telah diproduksi untuk memperkirakan volume penjualan.

4. Analisis bisnis. Dalam tahap ini diadakan evaluasi terhadap keseluruhan rencana pengembangan untuk mengetahui sampai seberapa jauh kemampuan ide atau barang yang akan diproduksi tersebut dapat menghasilkan laba. Pemilik usaha perlu meninjau ulang penjualannya, biaya dan proyeksi laba untuk memutuskan apakah telah memenuhi sasaran perusahaan. Tahap ini sering pula disebut analisis rugi dan laba dalam pengembangan gagasan. Kegiatan yang dilakukan dalam analisis bisnis ini antara lain:

a). Ramalan penjualan. Manajemen harus dapat memperkirakan proyeksi jumlah penjualan cukup tinggi untuk menghasilkan keuntungan yang diharapkan. Perlu pula diadakan survei terhadap hasil penjualan produk pesaing yang sejenis, agar dapat menentukan posisi produk dalam pasar, selain itu perlu disusun perkiraan penjualan minimum dan maksimum untuk mengantisipasi resiko yang mungkin akan terjadi.

b). Perkiraan biaya dan laba. Di ramalan penjualan dapat diperkirakan biaya dan laba. Metode analisis resiko dan laba adalah metode yang dapat digunakan untuk melihat perkiraan biaya yang harus dikeluarkan oleh industri tersebut dan perkiraan laba yang akan diperoleh.

5. Pengembangan dan uji produk. Setelah tahap analisis bisnis selesai dilakukan, tahap berikutnya adalah menjadi tanggung jawab bagian pengembangan, bagian rekayasa dan produksi untuk mewujudkan produk yang telah direncanakan tersebut secara fisik sampai menjadi produk yang siap dipasarkan. Dengan adanya uji produk perusahaan home industri akan mengetahui sejauh mana minat dan keinginan konsumen untuk membeli produk baru tersebut.

6. Strategi pemasaran produk. Setelah konsep produk lolos uji serta mendapatkan tanggapan positif dari calon konsumen, strategi pengenalan produk ke pasar mulai dipersiapkan, supaya konsumen secara luas dapat mengetahui produk baru yang telah dikeluarkan oleh industri tersebut dan dapat dikonsumsi untuk memenuhi keinginan dan kebutuhannya. Dalam melakukan promosi atau pengenalan produk baru pada konsumen, home indusri harus berusaha melakukan hal yang terbaik atau mempengaruhi konsumen dengan strategi yang menarik agar konsumen cepat untuk membeli produk baru tersebut.

7. Uji pasar. Uji pasar adalah tahap yang memadukan program pengembangan produk dengan program pemasaran. Tujuannya adalah untuk menguji produk dalam situasi pasar yang sebenarnya serta untuk menguji semua program pemasaran produk tersebut, seperti kebijakan harga dan pengemasan. Dengan diadakannya uji pasar, diharapkan hasil pengujian dapat memberikan kejelasan terhadap laba produk yang akan diperoleh serta peluang keberhasn penjualan pada homei setelah produk baru tersebut dipasarkan.

8. Pengenalan pasar. Setelah mendapat cukup informasi positif dalam tahap pengujian pasar, tahap selanjutnya diputuskan 
untuk memulai produksi dan memperkenalkannya atau menjualnya ke pasar. Dalam keputusan pengenalan produk, perlu dipertimbangkan empat aspek utama, yaitu pengenalan, tempat pengenalan, target konsumen yang ingin dicapai dan strategi pengenalan produk sehingga nantinya keseluruhan rencana pengembangan produk yang telah direncanakan bisa berjalan sesuai dengan harapan.

Beberapa strategi yang termasuk dalam modifikasi produk ini adalah:

1. Perbaikan kualitas. Strategi perbaikan kualitas ini dapat membantu pada peningkatan fungsi produk tersebut seperti: keawetan, kecepatan, dan kelezatan. Kualitas produk yang baik pasti banyak disukai oleh konsumen, karena pada dasarnya konsumen menginginkan barang yang bermanfaat dan berkualitas bagus untuk memenuhi kebutuhannya. Dengan adanya peningkatan produk barang yang dibeli oleh konsumen dapat meningkatkan volume penjualan pada home industri tersebut.

2. Perbaikan segi. Dalam hal ini home industri dapat menambah model dan variasi baru yang dapat meningkatkan keamanan atau perlindungan dan kepraktisan suatu produk, salah satunya adalah dengan merubah kemasan produk agdapat dikonsumsi untuk meonsumen. Kemasan produk yang kurang bagus dapat mempengaruhi minat konsumen untuk membeli produk tersebut, sehingga perusahaan akan banyak kehilangan konsumen. Sehingga demikian pengembangan produk terhadap kemasan harus segera dilakukan, agar konsumen tetap menyukai dan membeli produk tersebut.

3. Perbaikan corak. Di sini home industri lebih mengutamakan keindahan daripada yang lain. Untuk barang-barang seperti makanan dan barang konsumsi lainnya, pembungkusan dapat mencerminkan sebagai corak dapat terjadi bahwa sebagian langganan justru lebih menyukai corak yang lama. Kalau corak lama tersebut ditinggalkan berarti perusahaan dapat kehilangan sebagian langganannya sehingga demikian home industri dapat melakukan perubahan pada kemasan sebatas penambahan corak tetapi jangan merubah corak lkeuntungan yang dihardi ciri khas home industri tersebut.

Thamrin Abdullah dan Francis Tantri (2012:160-163) mengatakan bahwa keputusan produk meliputi:

1. Atribut produk, mengembangkan suatu produk mencakup penetapan manfaat yang akan disampaikan produk. Manfaat ini dikomunikasikan dan disampaikan oleh atribut produk seperti mutu, sifat, dan rancangan. Keputusan mengenai atribut ini amat mempengaruhi reaksi konsumen terhadap suatu produk, karena dengan adanya peningkatan mutu dan kualitas akan banyak konsumen yang tertarik dan mengkonsumsinya.

2. Merek. Merek adalah janji penjual untuk menyampaikan kumpulan sifat, dan manfaat kepada pembeli. Merek terbaik menjadi jaminan mutu yang akan dipertimbangkan oleh pelanggan karena pelanggan tidak hanya membeli atribut tetapi juga membeli manfaat. Oleh karena itu atribut harus lebih diarahkan menjadi manfaat yang fungsional.

3. Nilai merek. Merek bervariasi dalam besarnya pengaruh dan nilai di pasar. Beberapa merek umumnya tidak dikenal oleh kebanyakan pembeli karena pada umumnya merek hanya merupakan nama sebuah barang. Namun merek yang telah mempunyai nama terkenal dan memiliki nilai merek yang tinggi mempunyai penilaian tersendiri bagi pelanggan. Sebuah merek dengan nilai merek yang kuat merupakan aset yang sangat berharga bagi suatu perusahaan ataupun home industri untuk tetap mempertahankan kelangsungan hidup usahanya.

4. Strategi merek, sebuah perusahaan mempunyai empat pilihan kalau berbicara 
tentang strategi merek. Perusahaan dapat memperkenalkan perluasan lini (nama merek sudah ada diperluas ke bentuk, ukuran, dan aroma baru dari kategori produk yang sudah ada), perluasan merek (nama merek yang sudah ada diperluas ke kategori produk baru), multi merek (nama merek baru diperkenalkan dalam kategori produk yang sama), atau merek baru (nama merek baru dalam kategori produk baru).

5. Pengemasan, banyak produk yang ditawarkan ke pasar harus dikemas. Kemasan yang bagus dan menarik sangat diperlukan untuk menarik para pelanggan dan meningkatkan volume penjualan. Beberapa pemasar bahkan menyebut pengemasan sebagai $\mathrm{P}$ yang kelima, sesudah price, product, place dan promotion. Akan tetapi kebanyakan pemasar menganggap pengemasan sebagai suatu unsur dari strategi produk. Mengemas termasuk aktifitas merancang dan membuat wadah atau pembungkus untuk suatu produk yang akan dipasarkan. Kemasan bisa mencakup wadah utama dari produk, kemasan sekunder yang dibuang ketika produk akan digunakan, dan kemasan pengiriman yang perlu untuk menyimpan, mengenali, dan mengirimkan produk. Pemberian lebel juga merupakan bagian dari pengemasan dan berupa informasi tercetak yang ditempel pada kemasan untuk memberikan ciri khas tersendiri untuk merek. Secara tradisional, keputusan pengemasan terutama berdasarkaikutnya adalah menjadi produksi, fungsi primer dari kemasan adalah memberi tempat dan melindungi produk. Akan tetapi, dewasa ini berbagai faktor membuat pengemasan menjadi alat pemasaran yang penting karena konsumen akan cepat terg penelitian, pembuatan pertama yang langsung dapat dilihat. Semakin banyak swalayan berarti sekarang kemasan harus melakukan banydian dikembangkan meri menarik perhatian, menguraikan produk, g penelitian, pembuatan ualan. Perusahaan menypengiriman yang perlu emasan yang baik dapat menarik konsumen agar konsumen segera mengenali merek.

6. Pembuatan label, label bervariasi dari potongan kertas sederhana yang diikatkan pada produk sampai gambar grafik rumit yang merupakan bagian dari kemasan. Label mempunyai beberapa fungsi dan penjual harus memutuskan mana yang akan at pelanggan membelikhirnya penggunaan label yang tepat dapat mempromosikan produk dengan gambar yang menarik. Pembuatan label harus diperhatikan secara detail, agar tampilan yang dihasilkan dapat tperusahaan dan pengecn warna-warna dan fitur yang sesuai.

Penjualan merupakan fungsi yang paling penting dalam pemasaran karena menjadi tulang punggung kegiatan untuk mencapai enali, dan mengirimka u Swastha \& Ibnu Sukotjo, 2002:183).

Sedangkan Freddy Rangkuti (2009:58) mengatakan "volume penjualan merupakan jumlamodel kemasan yang ba dari kegiatan penjualan barang".

Di lain pihak Lamb (dalam Freddy Ranmikiran yang lebih matan "volume penjualan adalah pencapaian penjualan yang dinyatakan secara kuantitatif, dari segi fisik atau valume atau unit suatu produk".

Metode Penjualan Modern. Dalam melakukan penjualan, penjual harus sudah merencanakan langkah yang akan dilakukan sewaktu menghadapi pembeli. Ingatlah bahwa pembeli adalah "Raja" yang harus dapat servis sebaik-baiknya.

Ada dua metode yang dikenal dalam penjualan barang, yaitu:

\section{Personal selling}

Personal selling adalah penjualan barang secara lisan yang dilakukan oleh seorang penjual terhadap para pembeli secara langsung. Dalam hal ini penjual dituntut memiliki kecakapan dan ketrampilan dalam mempengaruhi pembeli sehingga 
terjadi persesuaian kepentingan. Penjual perlu memperhatikan tehnik pembicaraan yang biasa memberikan bimbingan dan motivasi kepada pembeli agar pembeli semakin tertarik untuk membeli produknya.

Sehubungan dengan pelaksanaan penjualan melalui personal selling, dikenal ada tiga suatu produk yang akan ai berikut:

a). Penjual dalam toko. Penjual dalam toko melayani para pengunjung toko. Kadang-kadang mereka dapat berbuat lebih banyak daripada para penjual keliling walaupun terbatas pada orangorang yang mengunjungi toko dan waktu yaiperoleh. Semakin tinggunjung tersebut karena pada dasarnya konsumen lebih suka mengunjungi toko daripada harus menunggu penjual keliling. Membeli dalam toko bisa memilih barang dengan banyak pilihan, berbeda dengan penjual keliling yang hanya membat pelanggan membelitas. Namun para calon pembeli dapat meninggalkan toko kalau penjual tidak bertindak cepat untuk menarik perhatian mereka. Jumlah omset sebuah toko tergantung pada jumlah orang yang tertarik pada toko itu.

b). Penjual keliling. Para penjual keliling mengunjungi calon pembeli ke kantorkantor daan selera konsumen selaluja penjual keliling bermula dari menarik perhatian pembeli pada suatu produk sehingga menimbulkan keinginan membeli dan akhirnya melakukan penjualan dengan mendapatkan pesanan. Penjual keliling cenderung harus mengeluarkan biaya untuk melakukan penjualan karena harus mendatangi pembeli secara langsung.

c). Penjual khusus. Terdapat bermacammacam penjual khusus. Ada yang memperkenalkan barang-barang baru yang biasanya membutuhkan kemampuan menjual yang lebih baik daripada menjual barang-barang yang sudah dikenal. Penjual khusus merupakan penjual satu macam barang.
2. Impersonal selling

Metode ini merupakan cara menjual tidak langsung. Metode ini menggunakan perwakilan untuk mempengaruhi konsumen. Hal itu menunjukkan adanya perubahan cara dari proses penjualan kepada pembeli menjadi aktif karena pengaruh perwakilan. Perwakilan dapat dilakukan melalui acara pertunjuksejenis dengan berbagm ruangan yang membolehkan pembeli melakukan gerakan atau tindakan sendiri sesuai dengan bimbingan atau keterangan yang diberikan oleh penjual.

Cara yang seperti ini lebih sukar dilakukan, karena penjual dituntut untuk mempunyai kemampuan mempengaruhi pembeli, memberikan pengarahan yang mudah dimengerti dan harus memperhatikan teknik dalam menarik para pembeli.

Faktor-faktor yang mempengaruhi volume penjualan:

1. Merek (Brand). Suatu produk yang dijual kepada masyarakat, biasanya dikenal melalui mereknya. Tanpa merek, orang akan sulit mengenal apalagi mencoba membelinya.

2. Pembungkus (Packaging). Pembungkus suatu produk akan memberikan suatu ciri khas yang akan mempertinggi nilai suatu produk. Perlu diketahui bahwa bisa terjadi, produk-produk yang sama kualitasnya dapat san yang bagus dan mgan yang berbeda hanya karena bentuk pembungkusnya. Pembungkus ini merupakan alat sebagai identifikasi untuk konsumen. Halhal lain tentang pembungkus adalah sebagai alat untuk melindungi produk tersebut agar mutu dan kondisinya selalu baik. Syarat-syarat pembungkus yang baik adalah menarik dan menciptakan gengsi, dapat melindungi dari kerusakan, praktis, baik ditinjau dari ukuran maupun bentuk.

3. Pelayanan (service). Pelayanan ini merupakan unsur dari upaya keberhasilan pemasaran atau penjualan suatu barang atau jasa. 


\section{METODE PENELITIAN}

Penelitian ini dilakukan di toko Roti MM Madiun. Penelitian ini menggunakan Deskriptif Kuantitatif yaitu Metode penelitian kuantitatif adalah suatu proses menemukan pengetahuan yang menggunakan data berupa angka sebagai alat menemukan keterangan mengenai apa yang ingin diketahui (Margono, 2004:105-106).

Metode penelitian yang digunakan dalam penelitian ini adalah penelitian Deskriptif. Best (dalam Sukardi, 2004:157) menyatakan bahwa penelitian deskriptif adalah metode penelitian yang berusaha menggambarkan dan menginterpretasi objek sesuai dengan apa adanya.

Variabel-variabel yang dilibatkan dalam penelitian ini adalah pengembangan produk (X) dan Volume Penjualan (Y). Variabel yang digunakan dalam penelitian ini terdiri dari dua variabel yaitu satu variabel bebas dan satu variabel terikat.

Untuk mendapatkan data yang diperlukan dalam peneg nantinya akan diprodnik pengumpulan data dengan studi lapangan. Adapun tehnik yang digunakan dalam study lapangan ini adalah:

1. Wawancara

Juliansyah Noor (2011:138) menyatakan "wawancara merupakan satu teknik pengumpulan data yang dilakukan dengan berhadapan secara langsung dengan yang diwawancarai tetapi dapat juga diberikan daftar pertanyaan dahulu untuk dijawab pada kesempatan lain.

Pada penelitian ini, peneliti menggunakharus dikeluarkan oleh ink memperoleh informasi bagaimana pengembangan produk berupa perubahan kemasan pada produk roti yang paling diminati oleh pembeli pada home industri MM Madiun.

\section{Dokumentasi}

Suharsimi Arikunto (2010:274) menyatakan "metode dokumentasi yaitu mencari data mengenai hal-hal atau variabel yang berupa catatan, transkip, buku, surat kabar, majalah, prasasti, notulen rapat, agenda dan sebagainya". Metode ini digunakan untuk memperoleh data tentang laporan jumlah penjualan home industri MM Madiun.

Dengan demikian, tehnik pengumpulan data dengan dengan dokumentasi ini yaitu memperoleh data dengan cara mencatat dokumen-dokumen tentang volume penjualan sebelum dan sesudah ada pengembangan produk yang telah dicapai oleh Toko Roti MM Madiun pada tahun 2012-2013.

Dari data dapat diketahui bahwa volume penjualan sebelum adanya pengembangan produk adalah 10823 unit sedangkan volume penjualan sesudah adanya pengembangan produk adalah 12583 unit. Dengan menggunakan analisis statistik deskriptif dapat diketahui jumlah volume penjualan sebelum adanya pengembangan produk sebesar rata-rata hitung (mean) sebesar 832.54. Median sebesar 891.00. Modus sebesar 532. Standar deviasi sebesar 175.686. Minimum sebesar 532. Maximum sebesar 1184. Sedangkan volume penjualan sesudah adanya pengembangan produk sebesar ratarata hitung (mean) sebesar 967.92. Median sebesar 983.00. Modus sebesar 997. Standar deviasi sebesar 71.351. Minimum sebesar 834. Maximum sebesar 1090.

\section{Populasi dan Sampel Penelitian}

Sugiyono (2008:80) menyatakan "populasi adalah wilayah generalisasi yang terdiri atas obyek atau subyek yang mempunyai kualitas dan karakteristik tertentu yang ditetapkan oleh peneliti untuk dipelajari dan kemudian ditarik kesimpulan". Populasi penelitian ini adalah laporan penjualan toko roti MM Madiun pada tahun 2012-2013.

Sampel $\mathrm{m}$ hal penggunaan, koni populasi. Suharsimi Arikunto (2010:174) mengatakan "sampel adalah sebagian atau wakil populasi yang diteliti. Adapun yang menjadi sampel dalam penelitian ini adalah laporan penjualan toko roti MM Madiun selama 6 bulan per minggu, yaitu mulai bulan 
Oktober sampai dengan Desember 2012 dan bulan Januari sampai dengan Maret 2013.

Tehnik pengambilan sampel yang digunakan dalam penelitian ini adalah teknik "Sampel Purposif (purposive sampling) yaitu pengambilan sampel apabila peneliti memiliki alasan alasan khusus tertentu berkenaan dengan sampel yang akan diambil" (Punaji Setyosari, 2010:172).

\section{Variabel Penelitian}

Dengan demikian, dalam penelitian ini terdapat dua variabel, yaitu variabel bebas (X) berupa pengembangan produk dan variabel terikat (Y) berupa Volume Penjualan. Adapun definisi operasional dalam penelitian ini adalah sebagai berikut:

\section{Pengembangan produk, yaitu upaya} perusahaan untuk senantiasa menciptakan produk baru, memperbaiki produk lama atau memodifikasi produk lama, agar selalu dapat memenuhi tuntutan pasar dan selera pelanggan.

2. Volume Penjualan, yaitu jumlah total yang dihasilkan dari kegiatan penjualan barang.

\section{HASIL PENELITIAN}

Dari hasil perhitungan dalam pengujian analisis deskriptif sebelum adanya pengembangan produk telah diperoleh data dari $\mathrm{N}$ sebanyak 13 , yang berada di atas nilai ratarata sebanyak $7 \mathrm{~N}$ atau 53,8\%. Sedangkan yang berada di bawah nilai rata-rata sebanyak $6 \mathrm{~N}$ atau $46,2 \%$. Sedangkan anal isis deskriptif sesudah adanya pengembangan produk telah diperoleh data dari $\mathrm{N}$ sebanyak 13, yang berada di atas nilai rata-rata sebanyak $8 \mathrm{~N}$ atau $61,5 \%$. Sedangkan yang berada di bawah nilai rata-rata sebanyak $5 \mathrm{~N}$ atau $38,5 \%$.

Berdasarkan analisis yang telah dilakukan tersebut, dapat dijelaskan bahwa pengembangan produk sangat dibutuhkan untuk meningkatkan volume penjualan.

Gunawan Adi Saputro (2010:193) yang menyatakan "perusahaan perlu mengembangkan hasil pendapatannya untuk masa mendatang dengan cara mengembangkan produk baru dan memperluas pasar produknya. Produk baru akan membentuk masa depan perusahaan, memperbaiki ataupun menggantikan produk yang lama sehingga mampu memelihara dan meningkatkan volume penjualan".

\section{HASIL ANALISIS DATA}

Hasil penelitian yang sudah dilakukan menunjukkan bahwa ada beda pengaruh pengembangan produk terhadap volume penjualan. Hal ini menunjukkan bahwa pengembangan produk sangat diperlukan untuk dapat meningkatkan volume penjualan. Selanjutnya adalah pembahasan untuk uji t:

Untuk uji $\mathrm{t}$ diperoleh nilai $\mathrm{t}_{\text {hit }}$ adalah 2.327 sedangkan $t_{\text {tab }}$ adalah 1,795, di lain pihak nilai $\mathrm{Sig}_{\text {tit }}$ adalah 0,038 sedangkan $\operatorname{Sig}_{\text {prob }} 0,05$. Hal ini berarti nilai $t_{\text {hitung }}>t_{\text {tabel }}$ $(2.327>1,795)$ atau $\operatorname{Sig}_{\text {hit }}<\operatorname{Sig}_{\text {prob }}(0,038<$ 0,05). Dengan demikian $\overline{\mathrm{H}_{0}}$ ditolak, artinya ada beda pengaruh pengembangan produk terhadap volume penjualan pada toko roti MM Madiun.

Dari hasil penelitian menunjukkan bahwa ada beda pengaruh pengembangan produk terhadap volume penjualan. Hal ini disebabkan adanya pengembangan produk untuk kemasan yang semakin bervariasi, sehingga dapat menarik konsumen untuk membeli. Oleh karena itu pengembangan produk sangat diperlukan untuk dapat meningkatkan volume penjualan.

\section{PENUTUP}

\section{Simpulan}

selling adalah penjuala pada toko roti MM Madiun baik. Hal ini dapat dilihat dari adanya berbagai variasi kemasan baru di dalam produk yang dihasilkannya, sehingga dang merupakan bagiann untuk membeli. Untuk 3 bulan penjualan sebelum adanya pengembangan produk rata-rata penjualan sebesar $832,5 \%$. Sedangkan untuk 3 bulan terakhir ini penjualan sesudah pen gembangan produk rata-rata mencapai $967,9 \%$. 
Volume penjualan pada toko roti MM Madiun cukup baik. hal tersebut terbukti dari setiap minggunya penjualan mengalami kenaikan. Hal ini dapat dilihat dari hasil analisis data volume penjualan sebelum dan sesudah pengembangan produk. Data volume penjualan sebelum pengembangan produk dari $\mathrm{N}$ sebanyak 13 , yang berada di atas nilai rata-rata sebanyak 7 minggu atau 53,8\%. Sedangkan yanya dan dapat menambaatarata sebanyak 6 minggu atau 46,2\%. Berdasarkan hasil analisis statistik deskriptif dengan jumlah $(\mathrm{N})$ sebanyak 13 diperoleh data sebagai berikut: (a) jumlah skor total sebesar 10823; (b) rata-rata hitung (mean) sebesar 832.54; (c) median sebesar 891.00; (d) modus sebesar 532; (e) standar deviasi sebesar 175.686; (f) minimum sebesar 532; (g) maximum sebesar 1184 .

Sedangkan volume penjualan sesudah pengembangan produk dari $\mathrm{N}$ sebanyak 13 , yang berada di atas nilai rata-rata sebanyak 8 minggu atau $61,5 \%$. Sedangkan yang berada di bawah nilai rata-rata sebanyak 5 minggu atau $38,5 \%$. Berdasarkan hasil analisis statistik deskriptif dengan jumlah (N) sebanyak 13 diperoleh data sebagai berikut: (a) jumlah skor total sebesar 12583; (b) ratarata hitung (mean) sebesar 967.92; (c) median sebesar 983.00; (d) modus sebesar 997; (e) standar deviasi sebesar 71.351; (f) nilai minimum sebesar 834; (g) nilai maximum sebesar 1090 .

Pengembangan produk mempunyai pengaruh terhadap volume penjualan pada toko roti MM Madiun. Hal tersebut terbukti dari hasil analisis uji t yaitu diperoleh nilai $t_{\text {bit }}$ adalah -2.327 sedangkan $t_{\text {aab }}$ adalah 1,795, di lain pihak nilai $\mathrm{Sig}_{\text {hit }}$ adalah 0,038 sedangkan $\mathrm{Sig}_{\text {prob }} 0,05$. Hal ini berarti nilai $\mathrm{t}_{\text {nitung }}>\mathrm{t}_{\text {tabel }}$ $(2.327>1,795)$ atau $\operatorname{Sig}_{\text {hit }}<\operatorname{Sig}_{\text {prob }}(0, \theta 38<$ $0,05)$. Dengan demikian $\mathrm{H}_{0}$ ditolak, artinya ada beda pengaruh pengembangan produk terhadap volume penjualan pada toko roti MM Madiun.

\section{Saran}

Adapun saran yang dapat dikemukakan dalam akhir penyusunan laporan penelitian ini antara lain sebagai berikut:

Pengembangan produk mempunyai pengaruh terhadap volume penjualan, oleh karena itu karyawan dan pemilik home industri toko roti tersebut harus bersungguhsungguh dalam mengembangkan produknya. Caranya dengan lebih memaksimalkan lagi pengembangan yang telah dilakukan, diharapkan selain melalui pengembangan pada kemasan, bisa dilakukan juga pada variasi rasa atau kualitas produk yang dihasilkan. Selain itu untuk melakukan pengembangan produk diperlukan keahlian dalam mengelolanya, sehingga pemimpin bisa memberikan pelatihan tentang bagaimana melakukan pengembangan produk yang baik, agar karyawan lebih mengerti bagaimana tahap-tahap ymempengaruhi konsumeat melakukan pengembangan produk. Pengembapula oleh masyarakat. B salah satu cara untuk meningkatkan volume penjualan dan menambah penghasilan untuk toko roti tersebut. Dengan adanya pengembangan produk, diharapkan konsumen tertarik dengan variasi baru yang telah diproduksi, sehingga tetap membeli barang konsumsi tersebut.

Bagi peneliti yang selanjutnya, sebaiknya untuk melakukan penelitian yang akan datang dapat menggunakan variabel lain yang lebih bervapengembangan produk ih banyak faktor-faktor yang dapat mempengaruhi volume penjualan selain pengembangan produk.

\section{DAFTAR PUSTAKA}

Agus Ahyary. 2002. Manajemen Produksi: Perencanaan Sistem Produksi. Yogyakarta: BPFE Yogyakarta.

Arman Hakim Nasution. 2006. Manajemen Industri. Yogyakarta: CV. Addi Offset. 
Basu Swastha dan Ibnu Sukotjo. 2002. Pengantar Bisnis Modern: Pengantar Ekonomi Perusahaan Modern. Yogyakarta: Liberty Yogyakarta.

Basu Swastha dan Irawan. 2008. Manajemen Pemasaran Modern. Yogyakarta: Liberty Yogyakarta.

Basu Swastha. 2002. Azas Azas Marketing. Yogyakarta: Liberty Yogy akarta.

Boyd, Walker, Larreche. 2000. Manajemen Pemasaran: Suatu Pendekatan Strategi Dengan Orientasi Global. Jakarta: Erlangga.

Buchari Alma. 2005. Kewirausahaan. Bandung: Alfabeta.

Duwi Priyatno. 2010. Teknik Mudah dan Cepat Melakukan Analisis Data Penelitian SPSS. Yogyakarta: Gava Media.

Freddy Rangkuti. 2009. Strategi Promosi yang enal. Penjual khusus meru us Integrated Marketing Communication. Jakarta: PT. Gramedia Pustaka Utama.

Gabriel Amin Silalahi. 2003. Metodologi Penelitian dan Studi Kasus. Sidoarjo: CV. Citra Media.

Gunawan Adisaputro. 2010. Manajemen Pemasaran: Analisis Untuk Perancangan Strategi Pemasaran. Yogyakarta: Sekolah Tinggi Ilmu Manajemen YKPN.

Juliansyah Noor. 2011. Metodologi Penelitian. Jakarta: Kencana Prenada Media Group.

Lili M. Sadeli dan Maman Ukas. 2000. Pengantar Bisnis Ilmu Menjual. Jakarta: PT. Bumi Aksara.
Margono. 2004. Metode Penelitian Pendidikan. Jakarta: PT. Rineka Cipta.

Nasution. 2004. Metode Researth: Penelitian Ilmiah. Jakarta: PT. Bumi Aksara.

Philip Kotler dan Kevin Lane Keller. 2009. Manajemen Pemasaran. Jakarta: Erlangga.

Philip Kotler dan Nancy Lee. 2007. Pemasaran di Sektor Publik: Panduan Praktis Untuk Meningkatkan Kinerja Pemerintah. Jakarta: PT. Indeks.

Punaji Setyosari. 2010. Metode Penelitian Pendidikan dan Pengembangan. Jakarta: Kencana Prenada Media Group.

Sugiyono. 2004. Metodologi Penelitian Administrasi. Bandung: CV. Alfabeta.

Sugiyono. 2008. Metode Penelitian Kuantitatif, $\mathrm{m}$ adanya pengembanndung: Alfabeta.

Suharsimi Arikunto. 2010. Prosedur Penelitian: Suatu Pendekatan Praktik. Jakarta: PT. Rineka Cipta.

Sukardi. 2004. Metodologi Penelitian Pendidikan: Kompetensi dan Praktiknya. Jakarta: PT. Bumi Aksara.

Thamrin Abdullah dan Francis Tantri. 2012. Manajemen Pemasaran. Jakarta: PT. Raja Grafindo Persada.

Ulber Silalahi. 2010. Metode Penelitian Sosial. Bandung: PT. Refika Aditama.

Zulian Yaual keliling cenderung hlitas: Produk dan Jasa. Yogyakarta: Ekonisia. 